\title{
SOLUSI PROBLEMATIKA UMAT DALAM PERSPEKTIF AL-QUR'AN
}

\author{
Oleh: Ali Mursyid dan Arison Sani \\ Dosen Institut Ilmu al-Qur'an (IIQ) Jakarta \\ Email: ali@iiq.ac.id
}

\section{Abstrak:}

Tulisan ini adalah hasil peneletian yang diselenggarakan dengan tujuan mencari solusi terbaik bagaimana menyelesaikan problematika umat yang semakin beragam, dengan berlandaskan pada al-Qur'an. Masalah yang diangkat dalam penelitian ini, dibatasi pada tiga masalah berikut: (1) Bagaimana ayat-ayat alQur'an memberi solusi pada persoalan kemiskinan umat Islam? (2) Bagaimana al-Qur'an memberi solusi pada persoalan kaum ḍu'afa di tengah-tengah masyarakat? (3) Bagaimana al-Qur'an memberi solusi pada konflik sosial yang akhir-akhir ini banyak terjadi? Penelitian ini adalah penelitian kualitatif, dengan jenis data kualitatif, Penelitian ini juga adalah jenis penelitian pustaka yang datanya diperoleh malalui penelusuran kepustakaan. Dalam penggalian dan analisa data, digunakan metode Tafsir Mauḍ $\bar{u}, \bar{i}$ (tematik), sementara itu pendekatan yang digunakan adalah pendekatan teologi dan pendekatan sosiologi. Setelah melalui pembahasan, penelitian ini menghasilkan tiga hal; Pertama, tentang solusi al-Qur'an bagi problem kemiskinan, yang dibagi dalam ranah individual, keluarga masyarakat dan negara. Pada ranah individual, untuk mengatasi problem kemiskinan, al-Qur'an mendorong muslim untuk bekerja keras. Pada ranah keluarga, menghadapi problem kemiskinan, al-Qur'an mewajibkan kepada setiap orang untuk menyantuni pihak yang memang wajib dinafkahi dalam suatu rumpun keluarga, terutama mereka yang kurang mampu. Pada ranah masyarakat, untuk mengatasi problem kemiskinan, al-Qur'an mensyariatkan zakat. Pada ranah pemerintah, al-Qur'an mewajibkan pemerintah untuk menyejahterakan warganya. Kedua, solusi al-Qur'an bagi kaum du'afá'. Dalam hal ini al-Qur'an menyebut hak-hak kaum ḍ'afa, kewajiban kita untuk memperhatikan mereka, imbalan dari Allah jika kita memperhatikan mereka, akibat jika kita menelantarkan mereka, dan juga mengenai cara memberdayakan mereka. Ketiga, solusi al-Qur'an untuk konflik sosial. Dalam menghadapi konflik sosial, al-Qur'an mengajarkan bahwa dalam menangani konflik, diperlukan etika. Al-Qur'an menganjurkan budaya kerja tim guna 
mengurangi konflik dan memupuk persaudaraan. Al-Qur'an menawarkan musyawarah sebagai mekanisme penyelesaian konflik. Selain itu, perdebatan yang baik juga bisa digunakan. AlQur'an juga memberi kesempatan untuk mengambil tindakan tegas jika cara damai tidak menyelesaikan masalah.

Kata kunci: kemiskinan, kaum ḍu'afä', konflik sosial, solusi al-Qur'an Abstract:

This study is a reult of research that is conducted to contribute for a best solution how to solve the problems of ummah, that are increasingly diverse, based on al-Quran. The problems that are questioned in this study restricted into three: (1) How do the verses of al-Quran solve the problem of the Muslim's poverty?; (2) How does al-Quran give solution in terms of the weak Muslims (du'afa)in soceity?; (3) How does al-Quran solve the social conflict that occurs recently? This study is quantitative research conducted by using quantitative data. Besides that, this research is literary research by collecting data in literatures in library. To anallise data, this research uses the method of Tafsir Maudu' $\bar{i}$ (thematic method), while its approach used is theological and sociological. The results of this study are: first, the quranic solution for the problems of poverty is divided into individual, family, social and state domain. In individual domain, to solve the problems of poverty, al-Quran motivates Muslims to work hard. In family domain, al-Quran obliges everyone to help every person in familly who is rightful to be helped, especially those are less fortunate people. While in society domain, alQuran obliges zakat. And in state domain, al-Quran constrains the goverment to make the society in posperity. The second, the solution for du'afa'. Al-Quran mentions some rights of du'afa, like the obligation of everyone to take care of them, the reward from Allah for who empowers them, the consequence of neglecting them and also how to empower them. The third, the solution for social conflict. To solve social conflict, al-Quran teach us to use moral ethicand also advises us to use cultural team work in decreasing conflict and establishing brotherhood. Besides that al-Quran proposes to use discussion (mushäwarah) and good debate. Al-Quran also allows to take decisive action when the soft mediation cannot be achieved.

Key words: Poverty, dúafá, social conlict, solution of al-Qur'an 


\section{Prolog}

Daerah Khusus Ibukota (DKI) Jakarta merupakan miniatur Indonesia, semua suku bangsa, agama, kepercayaan, budaya, kelas sosial ekonomi dan sebagainya, dari Sabang sampai Merauke dari Pulau Miangat sampai Pulau Rote, ada di DKI Jakarta. Konsekwensi logis dari itu adalah, bahwa selain menjadi tolok ukur kemajuan bangsa Indonesia, DKI Jakarta juga menjadi miniatur segala problematika sosial kemasyarakatan. Mulai dari problem kemiskinan, problem penduduk, problem sosial dan lain sebagainya.

Pada problem kemiskinan, angka kemiskinan di DKI Jakarta cenderung meningkat dari waktu ke waktu. Jumlah penduduk miskin di DKI Jakarta pada bulan September 2014 sebesar 412,79 ribu orang (4,09\%). Dibandingkan dengan Maret 2014 (393,98 ribu orang atau 3,92\%), jumlah penduduk miskin meningkat sebesar 18,81 ribu atau meningkat 0,17 poin. Sedangkan dibandingkan dengan September 2013 dengan jumlah penduduk miskin sebesar 371,70 ribu orang (3,72 \%), jumlah penduduk miskin meningkat 41,09 ribu atau meningkat 0,37 poin. Garis Kemiskinan (GK) bulan September 2014 sebesar Rp 459.560 per kapita per bulan, lebih tinggi dari Garis Kemiskinan Maret 2014 sebesar Rp 447.797 per kapita per bulan dan dari Garis Kemiskinan September 2013 sebesar Rp 434.322 per kapita per bulan. ${ }^{1}$ Dari data sederhana yang ada di BPS ini saja, kita bisa tahu bahwa angka kemiskinan di DKI Jakarta cenderung meningkat.

Selain angka banyaknya kaum miskin yang meningkat di DKI Jakarta, kaum du'afä' yang lainnya juga mengalami peningkatan dari waktu ke waktu. Anak atau orang terlantar misalnya, berdasarkan data Panti Sosial Bina Insan (PSBI) Bangun Daya 3, Cengkareng, Jakarta Barat (20/2010), jumlah Penyandang Masalah Kesejahteraan Sosial (PMKS) untuk kategori orang terlantar, setiap tahunnya mengalami peningkatan, bahkan cenderung meningkat. Dapat dilihat pada tahun 2011 terdapat 185 orang, pada tahun 2012 terdapat 138 orang, dan pada tahun 2013 terdapat 232 orang. ${ }^{2}$ Jadi data ini memberi tahu, bahwa selain angka kemiskinan, angka penduduk terlantar juga cenderung meningkat di Jakarta.

Selain orang terlantar, DKI Jakarta memiliki problem dengan banyaknya anak jalanan. Berdasarkan data dari Dinas Sosial DKI Jakarta, jumlah anak jalanan pada tahun 2009 sebanyak 3.724 orang, tahun 2010 meningkat menjadi 5.650 orang, dan pada tahun 2011 meningkat menjadi

\footnotetext{
1 BPS DKI Jakarta, dikakses secara online dari http://jakarta.bps.go.id/index.php? bWVudT0yMTA2JnBhZ2U9YnJzJnN1Yj0wNiZpZD01NzA=

2 Dinas Sosial DKI diakses dari http://dinsosdki.org/?page=detailberita\&id=04IdVvLi8 $\underline{\text { DUYFMTngoBjig }==}$
} 
7.315 orang. ${ }^{3}$ Dan pada Tahun 2013 dinas sosial DKI Jakarta meningkat sekitar 10 persen dari tahun lalu. ${ }^{4}$ Pada umumnya mereka bekerja sebagai pengemis, pengamen, pengelap kaca mobil, pedagang asongan, joki 3 in 1, dan parkir liar.

Kaum ḍ'afá' lainnya adalah para pengemis, gelandangan, pengamen dan yang semacamnya yang sering disebut dengan Penyandang Masalah Kesejahteraan Sosial (PMKS). Dalam hal ini, sering diberitakan di media, bahwa DKI Jakarta, adalah surga bagi pengemis, gelandangan, pengamen, pelacur jalanan, dan lainnya, untuk meraup rezeki. Ini terbukti dengan bertambahnya jumlah mereka yang ditertibkan Pemprov DKI Jakarta dari tahun ke tahun. Data Dinas Sosial DKI Jakarta, menyebutkan bahwa pada tahun 2012, PMKS yang terdiri dari gelandangan, pengemis, pengamen dan pelacur dan lainnya di DKI Jakarta mencapai 9.692 orang. Pada tahun 2013, meningkat menjadi 10.620 PMKS. ${ }^{5}$ Jumlah ini didapat dari jumlah mereka yang terjaring dalam operasi penertiban. Selain gelandangan, pengemis, pengamen dan pelacur, yang terhitung PMKS juga adalah orang dengan gangguan jiwa.

Khususnya orang dengan gangguan jiwa, dari data yang masuk ke beberapa lembaga pemasyarakatan yang ada di wilayah DKI Jakarta, diketahui bahwa jumlah orang gila semakin meningkat di Jakarta. Sebagai contoh mudah, Panti Sosial Bina Laras II (PSBL II), Cipayung, Jakarta Timur setiap harinya, setidaknya menerima tiga hingga empat orang gila baru hasil penertiban Satpol PP maupun Sudin Sosial di lima wilayah ibukota. $^{6}$

Dengan kecenderungan meningkatkanya jumlah kaum miskin, jumlah gelandangan, pengemis, pengamen, orang terlantar, anak jalanan, orang gila dan yang semacamnya, menjadikan DKI Jakarta sebagai daerah yang rawan konflik sosial. Dampak dari itu, konflik sosial dengan jenis konflik berbasis agama, etnik, politik, sumber daya alam, sumber daya ekonomi, antar aparat negara, tawuran warga, tawuran antar pelajar dan antar organisasi kemasyarakatan (Ormas), penghakiman massa, pengeroyokan dan lain-lain, setiap saat bisa terjadi di DKI Jakarta.

\footnotetext{
${ }^{3}$ Harian Kompas Online diakses dari http://megapolitan.kompas.com/read/2011/08 /24/1641249/Jumlah.Anak.Jalanan.Meningkat.Signifikan

4 http://www.indonesiafightpoverty.com/2014/04/02/butuh-keterlibat an-multi-pihak-atasijumlah -anak-jalanan/

${ }^{5}$ Data BPS Dinas Sosial DKI Jakarta

${ }^{6}$ Dari berita Online media Megapolitan, diakses dari http://www.beritasatu.com/pelayananpublik/185757-terima-4-orang-gila-setiap-hari-panti-sosial-overload.html
} 
Di satu sisi wilayah DKI Jakarta, sarat dengan berbagai problematika sosial, di sisi lain DKI Jakarta adalah Ibu Kota Negara yang sarat dengan prestasi dalam kancah MTQ (Musabaqah Tilawatil Qur'an). Beberapa kali DKI Jakarta tercatat sebegai pemenang dalam kancah MTQ nasional. Karena itulah ada baiknya jika kemudian untuk berbagai problematika umat di DKI, dicarikan solusinya dari ayat-ayat al-Qur'an. Dalam konteks inilah, penelitian mengenai Solusi Problematika Umat menurut Perspektif alQur'an ini dilaksanakan. Dalam hal ini DKI sebagai kasus saja. Kenapa dipilih DKI? Karena ia miniatur Indonesia. Dengan meneliti DKI, diharapkan hasilnya tidak berbeda jauh dengan meneliti Indonesia.

Sementara itu tuntutan agar al-Qur'an dapat berperan dan berfungsi dengan baik sebagai pedoman dan petunjuk hidup umat manusia, terutama di zaman modern ini, tidak akan berhenti. Oleh sebab itu, tidaklah cukup kalau al-Qur'an hanya dibaca sebagai rutinitas belaka dalam kehidupan sehari-hari, tanpa memahami maksud, mengungkap isi, serta mengetahui prinsip-prinsip yang terkandung di dalamnya. ${ }^{7}$ Pemeliharaan terhadap alQur'an dan menjadikannya menyentuh realitas kehidupan adalah menjadi suatu yang niscaya. Salah satu bentuknya adalah dengan memberinya interpretasi sesuai dengan problematika masyarakat yang berkembang. ${ }^{8}$

Untuk itulah melalui penelitian ini, peneliti berusaha mengelaborasi ayat-ayat al-Qur'an yang berisi isyarat bagaimana menyelesaikan problematika sosial yang ada dan berkembang sekarang ini, khususnya mengenai problematika kemiskinan umat, probelmatika kaum ḍu'afä' di tengah-tengah masyarakat dan terkait konflik-konflik sosial yang belakangan kerap terjadi di masyarakat.

Berdasarkan latar belakang masalah, maka masalah penelitian ini adalah sebagaimana dirumuskan dalam pertanyaan-pertanyaan berikut: 1) Bagaimana ayat-ayat al-Qur'an memberi solusi pada persoalan kemiskinan umat Islam; 2) Bagaimana al-Qur'an memberi solusi pada persoalan kaum d̦u'afá' di tengah-tengah masyarakat?; 3) Bagaimana al-Qur'an memberi solusi pada konflik sosial yang akhir-akhir ini banyak terjadi?

Sependek pengetahuan peneliti, belum ada penelitian yang sama persis, baik dari segi tema maupun masalah yang dibahas, dengan penelitian ini. Namun demikian, sejauh penelusuran peneliti, ada beberapa hasil penelitian dan karya ilmiah terdahulu yang terkait, berikut ini: Pertama,

\footnotetext{
${ }^{7}$ Muhammad Shahrur pun mengakui bahwa di zaman kontemporer ini, al-Qur'an perlu ditafsirkan sesuai dengan tuntutan zaman yang dihadapi umat manusia, Lihat, Muhammad Shahrur, al-Kitāb wa al-Qur'ān, Qirā'ah Mu'āsirah, (Damaskus: TP, TT), 33

${ }^{8}$ M. Quraish Shihab, "Fungsi dan Peran Wahyu dalam Kehidupan Masyarakat" dalam Membumikan al-Qur'an, (Bandung: Mizan, 2003), 88
} 
Tafsir Tematik Al-Qur'an dan Pemberdayaan Kaum Du'afá', sebuah karya tafsir tematik yang ditulis oleh Tim Penulis dan diterbitkan oleh Kementerian Agama RI, pada tahun 2008. Karya ini tidak bicara dan tidak membahas problematika umat secara luas dan hanya membahas persoalam kaum du'afá' saja. Sementara dalam penelitian ini tidak hanya sebatas membahas kaum du'afá', melainkan lebih luas lagi, menyangkut kemiskinan umat dan konflik-konflik sosial yang terjadi dan berkembang.

Kedua, Tafsir Tematik Al-Qur'an dan Isu-Isu Kontemporer, Jilid I dan II, ditulis oleh Tim Penulis dan diterbitkan oleh Kementerian Agama RI, tahun 2012. Dalam karya ini, dibahas berbagai isu-isu kontemporer dalam kehidupan berbangsa, bernegara dan beragama umat Islam. Pembahasannya sangatlah luas. Sementara penelitian ini, pembahasannya sangat sepesifik, yaitu hanya terkait dengan problematika sosial yang berhubungan dengan kemiskinan umat Islam, kaum ḍu'afá' dan konflik-konflik sosial.

Ketiga, karya ilmiah berbahasa Arab, Al-Qur'ān wa al-Mutaghayyurät al-Ijtimāiyyah wa al-Tärikhiyyah, yang ditulis oleh Muhammad Abu alQasim Haj Muhammad, diterbitkan oleh Dār al-Sāqi, Beirut, Libanon, tahun 2011. Dalam karya ilmiah ini, dijelaskan secara filosofis dan akademis tentang bagaimana seharusnya memberlakukan dan memfungsikan alQur'an di tengah-tengah perubahan dan dinamika kehidupan. Buku ini memberi sumbangan teori dan perspektif terhadap penelitian ini.

Penelitian ini adalah penelitian kualitatif, dengan jenis data kualitatif. Penelitian ini juga adalah jenis penelitian pustaka yang datanya diperoleh malalui penelusuran kepustakaan, terkait dengan tema yang sedang dibahas. Sumber data primer dari penelitian ini adalah ayat-ayat al-Qur'an dan tafsirnya, khususnya ayat-ayat al-Qur'an yang terkait dengan tema kemiskinan, kaum ḍ'afá' dan konflik sosial. Sedangkan data sekunder penelitian ini adalah kamus, ensiklopedi, jurnal-jurnal ilmiah terkait, dan buku-buku serta website-website terkait.

Sesuai dengan rumusan masalah dan sumber data penelitian ini, maka dalam penggalian dan analisa data, metode yang digunakan adalah metode Tafsir Maudhü'ì (tematik). Menurut al-Farmāwì bahwa ada tujuh langkah dalam sistematika tafsir maudh $\bar{u}, \bar{i}^{9}$. Kemudian tujuh langkah tersebut dikembangkan oleh M. Quraish Shihab. ${ }^{10}$

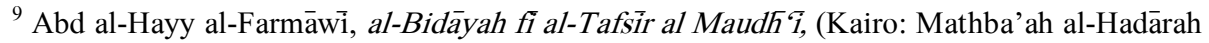
al-Arabiyah, , 1977), 6.

${ }^{10}$ Berikut ini langkah-langkah melakukan penggalian data dan analisa penelitian dan kajian melalui tafsir al-maudhü'í: 1) Menetapkan masalah yang akan dibahas; 2) Menghimpun seluruh ayat-ayat al-Qur'an yang berkaitan dengan masalah tersebut: 3) Menyusun uruturutan ayat terpilih sesuai dengan perincian masalah dan atau masa turunnya, sehingga
} 


\section{Pembahasan}

\section{Solusi al-Qur'an untuk Problem Kemiskinan Apa dan Siapa Saja yang Disebut Miskin}

Dalam Kamus Besar Bahasa Indonesia, kata "miskin" diartikan sebagai tidak berharta benda; serba kekurangan (berpenghasilan rendah). Sedangkan kata yang berdekatan dengan miskin adalah fakir, yang diartikan dalam kamus tersebut dengan tiga pengertian, yaitu pertama, orang yang sangat berkekurangan dan terlalu miskin. Kedua, orang yang dengan sengaja membuat dirinya menderita kekurangan untuk mencapai kesempurnaan batin. Ketiga berarti aku (bagi pengarang dalam syair dan sebagainya) ${ }^{11}$

Dari bahasa aslinya (Arab) kata miskin terambil dari kata sakana yang berarti diam atau tenang ${ }^{12}$, sedang faqir dari kata faqr yang pada mulanya berarti tulang punggung. Faqir adalah orang yang patah tulang punggungnya, dalam arti bahwa beban yang dipikulnya sedemikian berat sehingga "mematahkan" tulang punggungnya.

Pengertian leksikal dari kamus seperti di atas belum sepenuhnya dapat membantu untuk menjelentrehkan pengertian apa itu kemiskinan secara lebih jelas. Dalam al-Qur'an dan Sunnah juga nampak tidak diketemukan pengertian tentang miskin dan fakir. Karena itulah, sebagian ulama, terutama kalangan fuqahā, memberikan definisi yang berbeda tentang pengertian miskin dan fakir.

Imam al-Qurthubi mencatat sembilan pendapat yang berbeda tentang pengertian kedua istilah tersebut. Salah satu di antaranya adalah miskin berarti orang yang memiliki penghasilan tetapi tidak dapat mencukupi

terpisah antara ayat Makkỉ dan Madanī. Hal ini untuk memahami unsur pentahapan dalam pelaksanaan petunjuk-petunjuk al-Qur'an; 4) Mempelajari/memahami korelasi (munāsabāt) masing-masing ayat dengan surah-surah di mana ayat tersebut tercantum (setiap ayat berkaitan dengan terma sentral pada suatu surah); 5) Melengkapi bahan-bahan dengan hadishadis yang berkaitan dengan masalah yang dibahas; 6) Menyusun outline pembahasan dalam kerangka yang sempurna sesuai dengan hasil studi masa lalu, sehingga tidak diikutkan hal-hal yang tidak berkaitan dengan pokok masalah; 7) Mempelajari semua ayat yang terpilih secara keseluruhan dan atau mengkompromikan antara yang umum dengan yang khusus, yang mutlak dan yang relatif, dan lain-lain sehingga kesemuanya bertemu dalam muara tanpa perbedaan atau pemaksaan dalam penafsiran; 8) Menyusun kesimpulan penelitian yang dianggap sebagai jawaban al-Qur'an terhadap masalah yang dibahas. Abd al-Hayy alFarmāwì, al-Bidāyah fí al-Tafsìr al Maựū'ī, (Kairo: Mathba'ah al-Hadārah al-Arabiyah, , 1977), 61-62

${ }^{11}$ Departemen Pendidikan dan Kebudayaan, Kamus Besar Bahasa Indonesia, (Jakarta: Balai Pustaka, TT), 749 dan 312

${ }^{12}$ Kata sakana terdiri dari tiga huruf, sin, kaf dan nun, yang bermakna dasar diam atau tenang, sebagai lawan kata dari berguncang dan bergerak. Lihat Ibnu Faris, Mu'jam Maqāyis al-Lughah, 464. 
kebut uhan keluarganya, sedangkan fakir adalah orang yang sama sekali tidak memiliki penghasilan. ${ }^{13}$

Sebagian ulama berpendapat bahwa fakir adalah orang yang berpenghasilan kurang dari setengah kebutuhan pokoknya, sedang miskin adalah yang berpenghasilan di atas itu, namun tidak cukup untuk menutupi kebutuhan pokoknya. Ada juga yang mendefinisikan sebaliknya, sehingga menurut mereka keadaan si fakir relatif lebih baik dari si miskin. ${ }^{14}$ Meskipun ditemukan beragam pendapat mengenai pengertian miskin dan fakir, satu hal yang jelas adalah baik fakir maupun miskin adalah kelompok orang yang tidak memiliki kemampuan untuk memenuhi kebutuhan hidupnya secara layak.

Masalahnya apa yang disebut hidup layak itu sendiri, tidak seragam lagi dalam definisinya. Dan karena tidak ada kriteria yang jelas tentang batas-batas ukuran kemiskinan dan kefakiran dari teks al-Qur'an maupun Hadis Nabi SAW., hal ini menyebabkan ukuran dan standar hidup layak di masing-masing mayarakat yang berbeda maka akan berbeda pula. Tetapi bagaimanapun, yang pasti adalah bahwa kelompok miskin dan juga fakir tersebut ada. Dan al-Qur'an menjadikan setiap orang yang memerlukan sesuatu sebagai fakir atau miskin, yang harus dibantu. ${ }^{15}$

\section{Wacana Kemiskinan di Kalangan Umat Islam}

Para ulama berbeda pendapat tentang posisi kemiskinan bila dibandingkan dengan kekayaan. Pendapat ulama kelompok pertama, kelompok yang memuji-muji kemiskinan dan kefakiran sebagai sesuatu yang lebih baik dari pada kekayaan. Pandangan ini mengambil argumen dari beberapa ayat al-Qur' an yang memuji-muji orang fakir, di antaranya adalah QS. al-Baqarah: 273 yang artinya:

"(Apa yang kamu infakkan) adalah untuk orang-orang fakir yang terhalang (usahanya karena jihad) di jalan Allah, sehingga dia yang tidak dapat berusaha di bumi ; (orang lain) yang tidak tahu, menyangka bahwa mereka adalah orang-orang kaya karena mereka menjaga diri (dari meminta-minta). Engkau (Muhammad) mengenal mereka dari ciri-cirinya, mereka tidak meminta paksa kepada orang lain. Apa pun harta yang baik yang kamu infakkan, sungguh Allah Maha Mengetahui”. (QS. al-Baqarah: 273)

\footnotetext{
${ }^{13}$ Al-Qurțūbi, Al-Jāmi' al-Ahkām, jilid 8, (Beirut: Dar Fikr, 1999), 151

14 M Quraish Shihab, Wawasan Al-Qur'an: Tafsir Maudhu'i atas Pelbagai Persoalan Ummat,(Bandung: Penerbit Mizan, TT), 442

15 M. Quraish Shihab, Wawasan Al-Qur'an: Tafsir Maudhu'i atas Pelbagai Persoalan Ummat,(Bandung: Penerbit Mizan, TT), 442
} 
Demikian juga ayat yang memerintahkan Nabi SAW. untuk tidak mengusir orang-orang miskin yang taat kepada Allah SWT sebagaimana diisyaratkan dalam QS. al-An'ām: 52), yang artinya:

"Janganlah engkau mengusir orang-orang yang menyeru Tuhannya pada pagi dan petang hari, mereka mengharap keridhaan-Nya. Engkau tidak memikul tanggungjawab sedikit pun terhadap perbuatan mereka, dan mereka tidak memikul tanggungjawab sedikit pun terhadap perbuatanmu, yang menyebabkan engkau berhak mengusir mereka, sehingga engkai termasuk orang-orang yang dzalim" (QS. al-An'ām: 52)

Ada juga Hadis-Hadis yang dijadikan sebagian ulama untuk mendukung kemiskinan. Di antaranya yang sangat terkenal adalah yang artinya: "Ya Tuhan, hidupkanlah aku dalam kemiskinan dan matikanlah aku dalam kemiskinan dan bangkitkanlah aku dari kematian bersama orangorang yang miskin".

Di samping argumen normatif di atas, banyak juga praktik beragama yang dilakukan oleh para ulama, khsususnya dari kalangan sufi pada masa awal dan pertengahan, yang memilih menjadi miskin. Ungkapan yang populer diantaranya adalah, "Tuhan memuliakan kemiskinan dan menjadikannya derajat khusus orang-orang miskin yang telah melepaskan semua hal yang lahir dan batin dan benar-benar menghadap hanya kepada Allah swt"16

Ulama kelompok kedua, memandang kekayaan sebagai sesuatu yang lebih utama dari pada kemiskinan. Di antara argumen yang dikemukakan adalah bahwa kekayaan itu adalah salah satu sifat Tuhan, sedangkan kemiskinan tidak dapat dinisbatkan kepada-Nya. Selain itu juga, argumen ulama kelompok kedua ini dikuatkan oleh banyak ayat dan hadis Nabi yang memuji orang yang menginfakkan harta di jalan Allah. Berinfak sendiri, biasanya, dilakukan oleh mereka yang tidak lagi berkubang dalam kemiskinan.

Dari dua pandangan kedua kelompok ulama di atas, sekilas ada kontradiksi di dalam Islam, khusunya al-Qur'an mengenai kemiskinan. Bila ada kesan adanya kontradiksi di dalam al-Qur'an maka sesungguhnya karena disebabkan oleh kekurangan manusia dalam memahami ayat-ayat suci tersebut. ${ }^{17}$ Yang perlu digaris bawahi adalah, tidak ada ayat yang menyuruh

\footnotetext{
${ }^{16}$ Departemen Agama RI, Al-Qur'an dan Pembderdayaan Kaum Du'fá', Jilid 2, (Jakarta: Depag RI, 2008), 49.

${ }^{17}$ Pada masyarakat yang masih sederhana susunan organisasinya, mungkin kemiskinan bukan merupakan problem sosial, karena mereka menganggap bahwa semuanya telah ditakdirkan, sehingga tidak ada usaha-usaha untuk mengatasinya. Pada masyarakat modern yang kompleks, kemiskinan menjadi suatu problema sosial. Seorang bukan merasa miskin karena
} 
orang menjadi miskin. Sebaliknya spirit ayat-ayat al-Qur'an adalah menyuruh agar orang bekerja keras, tangguh dan bekerja secara cerdas. Dalam konteks penjelasan mengenai pandangan al-Qur'an tentang kemiskinan ternyata ditemukan sekian banyak ayat-ayat al-Qur'an yang memuji kecukupan, bahkan al-Qur'an menganjurkan untuk memperoleh berbagai kelebihan.

Sejak dini pula Kitab Suci ini mengingatkan Nabi Muhammad saw. tentang betapa besar anugerah Allah kepada beliau, yang antara lain menjadikannya berkecukupan (kaya) setelah sebelumnya papa. Sebagaimana disampaikan Allah dalam QS. Al-Ḍuhā [93]: 8).

"Seandainya kecukupan atau kekayaan tidak terpuji, niscaya ia tidak dikemukakan oleh ayat di atas dalam konteks pemaparan anugerah llahi. Berupaya untuk memperoleh kelebihan, bahkan dibenarkan oleh Allah walau pada musim ibadah haji sekalipun. Allah berfirman: "Tidak ada dosa bagi kamu untuk mencari fadhl (kelebihan) dari Allah (di musim haji)" (QS. AlBaqarah [2]: 198).

Di sisi lain, al-Qur'an mengecam mereka yang mengharamkan hiasan duniawi yang diciptakan Allah bagi umat manusia (QS. Al-A'raf [7]: 32), dan menyatakan bahwa Allah menjanjikan ampunan dan anugerah yang berlebih, sedang setan menjanjikan kefakiran (QS. Al-Baqarah [2]: 268).

Tak mengherankan jika dalam literatur keagamaan ditemukan ungkapan, "Hampir saja kekafiran itu menjadi kekufuran", karena Nabi Saw.. sering berdoa, "Ya Allah, Aku berlindung kepada-Mu dari kekufuran, kefakiran" (HR Abu Dawd). "Ya Allah, Aku berlindung kepada-Mu dari kefakiran, kekurangan dan kehinaan, dan Aku berlindung pula dari menganiaya dan dianinya "(HR Ibnu Majah dan al-Hākim). Meskipun demikian, Islam tidak menjadikan banyaknya harta sebagai tolok ukur kekayaan, karena kekayaan yang sebenarnya adalah kekayaan hati dan kepuasannya.

\section{Indikator Kemiskinan dalam al-Qur'an}

Di dalam al-Qur'an terdapat sekitar 22 ayat yang berbicara tentang kemiskinan. Dari ayat-ayat tersebut dapat diketahui indikator kemiskinan dengan berbagai aspeknya. Pertama, kemiskinan terkadang dikaitkan dengan orang yang kekurangan makan, sehingga kepada mereka perlu diberikan makanan sebagaimana firman Allah SWT dalam al-Qur'an Surat Al-Hāqah:

kurang makan, pakaian atau perumahan, akan tetapi karena harta miliknya dianggap tidak cukup untuk memenuhi taraf kehidupan yang ada. Hal ini terlihat di kota-kota besar. Soerjono Soekanto, Sosiologi Suatu Pengantar, (Jakarta: Rajawali Press, 1982), 379 
34, “Wa lā yahuḍ̣u 'alā tăām al-miskīn” lihat pula dalam QS. AlMuddhathir: 44, QS. Al-Fajr: 18, QS. Al-Mā'ūn: 3, QS.al-Mujādilah: 4, QS. Al-Māidah: 89. Adapun makanan yang diberikan pada orang-orang miskin itu adalah makanan yang halal dan baik. 'Hai sekalian manusia, makanlah yang halal lagi baik dari apa yang terdapat di bumi, dan janganlah kamu mengikuti langkah-langkah setan, karena sesungguhnya setan itu adalah musuh yang nyata bagimu" QS. Al-Baqarah:168. lihat pula (QS. Al-Māidah: 88, QS. Al-Anfāl: 69, QS. Yünus: 59, QS. al-Nahl; 114).

Kedua, kemiskinan dapat dilihat dari jenis pekerjaannya. QS. AlKahfi:79 menyatakan "Adapun bahtera itu adalah milik orang-orang miskin yang bekerja di laut dan aku bertujuan merusakan bahtera (perahu) itu. Karena dihadapan mereka ada seorang raja yang merampas tiap-tiap bahtera". Ayat ini menjelaskan tentang dialog Nabi Musa dengan Nabi Khidir. Musa mewakil generasi muda dan Nabi Khidir mewakili generasi Tua, keduanya bertukar informasi tentang tolok ukur kemiskinan yang dikaitkan dengan jenis pekerjaan. Dalam ayat ini dijelaskan tentang para nelayan tradisional yang bekerja memeras keringat, membanting tulang, mempertaruhkan nyawanya di lautan. Mereka menggunakan otot dan tenaga dengan posisi sebagai produsen yang menghasilkan ikan hasil tangkapannya. Sementara hasil jerih payahnya ini sering dimainkan oleh para tengkulak yang membelinya dengan harga murah. Fenomena ini juga terjadi pada pekerjaan lainnya seperti kalangan petani dan buruh.

Ketiga, indikator kemiskinan dilihat dari sisi pemberian hak-haknya, yaitu mereka yang kehilangan hak dan kesempatan untuk meraih kesuksesan, seperti hak mendapat pekerjaan, pendidikan, kesehatan, keamanan, perlindungan hukum, kesempatan berprestasi dalam kehidupan dan sebagainya.

Keempat, indikator kemiskinan berdasarkan al-Quran dapat dilihat dari segi hilangnya penghargaan atau penghormatan orang lain kepadanya. Yaitu mereka tidak dipedulikan dan tidak diperhitungkan. Sehingga secara psikologis mereka juga akan merasa menderita.

\section{Faktor Penyebab Kemiskinan}

M. Quraish Shihab menuliskan bahwa dalam bahwa faktor utama penyebab kemiskinan adalah sikap berdiam diri, enggan, atau tidak berusaha. Keengganan berusaha adalah penganiayaan terhadap diri sendiri, sedang ketidak mampuan berusaha antara lain disebabkan oleh penganiyaan manusia 1ain. Ketidak-mampuan berusaha yang disebabkan oleh orang lain diistilahkan pula dengan kemiskinan struktural. Kesan ini lebih jelas lagi bila diperhatikan bahwa jaminan rezeki yang dijanjikan Tuhan, ditujukan 
kepada makhluk yang dinamainya dābbah, yang arti harfiahnya adalah yang bergerak.

"Tidak ada satu dabbah pun di bumi kecuali Allah yang menjamin rezekinya" (QS. Hūd [11]: 6).

Ayat ini "menjamin" siapa yang aktif bergerak mencari rezeki, bukan yang diam menanti. Lebih tegas lagi dinyatakannya bahwa, "Allah telah menganugerahkan kepada kamu segala apa yang kamu minta (butuhkan dan inginkan). Jika kamu menghitung-hitung nikmat Allah, niscaya kamu tidak mampu menghinggakannya. Sesungguhnya manusia sangat aniaya lagi sangat kufur”. (QS. Ibrāhim [14]: 34).

Pernyataan al-Qur'an di atas dikemukakannya setelah menyebutkan aneka nikmat-Nya, seperti langit, bumi, hujan, laut, bulan, matahari, dan sebagainya. Sumber daya alam yang disiapkan Allah swt. untuk umat manusia tidak terhingga dan tidak terbatas. Seandainya sesuatu telah habis, maka ada alternatif lain yang disediakan Allah selama manusia berusaha. Oleh karena itu, tidak ada alasan bahwa sumber daya alam terbatas, tetapi sikap manusia terhadap pihak lain, dan sikapnya terhadap dirinya itulah yang menjadikan sebagian manusia tidak memperoleh sumber daya alam tersebut.

Selain itu semua, faktor penyebab kemiskinan juga bisa bersumber pada adanya pemahaman yang kurang tepat mengenai beberapa istilah agama, seperti zuhud, qanā'ah, sabar, tawakal dan syukur. ${ }^{18}$

\section{Pengentasam Kemiskinan}

\section{a. Pada Ranah Individu: Peningkatan Semangat Kerja}

Kerja dan usaha merupakan cara utama yang ditekankan oleh alQur'an, karena hal inilah yang sejalan dengan naluri manusia, sekaligus juga merupakan kehormatan dan harga dirinya.

"Dijadikan indah dalam (pandangan) manusia kesenangan kepada syahwat, berupa wanita (lawan seks), harta yang banyak dari jenis emas dan perak, kuda pilihan, binatang ternak, dan sawah ladang. Itulah kesenangan hidup duniawi. dan di sisi Allah tempat kecuali yang baik". (QS. Ali 'Imrān: 14).

Ayat ini secara tegas menggarisbawahi dua naluri manusia, yaitu naluri seksual yang dilukiskan sebagai "kesenangan kepada syahwat wanita", dan naluri kepemilikan yang dipahami dari ungkapan (kesenangan kepada) "harta yang banyak". Sementara pakar menyatakan bahwa seakanakan al-Qur'an menjadikan kedua naluri itu sebagai naluri pokok manusia.

\footnotetext{
${ }^{18}$ Departemen Agama, Loc.Cit. dan baca juga Qodi Azizy, Cara Kaya dan Menuai Surga (Jakarta: Reneeisan, 2005), 34
} 
Bukankah teks ayat tersebut membatasi ( $\underline{h}$ assr) kesenangan hidup duniawi pada hasil penggunaan kedua naluri itu?

Ibnu Khaldun dalam Muqaddimah-nya, menjelaskan bagaimana naluri kepemilikan itu kemudian mendorong manusia bekerja dan berusaha. Hasil kerja tersebut apabila mencukupi kebutuhannya -dalam istilah agama-disebut rizqi (rezeki), dan bila melebihinya disebut kasb (hasil usaha).

Dari sini dapat disimpulkan bahwa jalan utama yang diajarkan alQur'an untuk pengentasan kemiskinan adalah kerja dan usaha. Puluhan ayat yang memerintahkan dan mengisyaratkan kemuliaan bekerja.

"Apabila engkau telah menyelesaikan satu pekerjaan, kerjakanlah dengan sungguh-sungguh (pekerjaan yang lain, agar jangan menganggu), dan hanya kepada Tuhanmu sajalah hendaknya kamu mengharap" (QS. al-Inshirah [94]: 7-8).

Rasulullah SAW. pernah bersabda: "Salah seorang di antara kamu mengambil tali, kemudian membawa seikat kayu bakar di atas punggungnya lalu dijualnya, sehingga ditutup Allah air mukanya, itu lebih baik daripada meminta-minta kepada orang, baik ia diberi maupun ditolak”. (HR Bukhāri).

Kalau di tempat seseorang berdomisili, tidak ditemukan lapangan pekerjaan. al-Quran menganjurkan kepada orang tersebut untuk berhijrah mencari tempat lain. Barang siapa berhijrah di jalan Allah niscaya mereka mendapat di muka bumi tempat yang luas lagi rezeki yang banyak (QS. AlNisā' [4]: 100).

\section{Meluruskan Pemahaman Terhadap Beberapa Istilah Agama}

Zuhud, kata zuhud berasal dari kata zuhd yang mengandung arti ketidaksenangan terhadap sesuatu yang biasanya disenangi. ${ }^{19}$ Selama ini sikap zuhud kadang juga diidentikan dengan gaya hidup miskin. Padahal berdasarkan pengertian zuhud di atas, tidaklah demikian. Justru kualitas zuhud seseorang bisa dilihat manakala sesorang memiliki kesempatan yang luas dan mudah untuk meraih harta, kemudian dia tidak mengambilnya, atau dia mengambilnya (karena memang halal dan baik) lalu kemudian menunaikan segala kewajiban agamanya yang berkaitan dengan harta

\footnotetext{
${ }^{19}$ Lihat Ibnu Fāris, Mu'jam Maqāyis al-Lughah, h. 464. Kata zuhd ini hanya terulang sekali di dalam al-Qur'an, tepatnya di dalam QS. Yüsuf: 20, yang artinya: "Dan mereka menjualnya (Yüsuf) dengan harga rendah, yaitu beberapa dirham saja, sebab mereka tidak tertarik kepadanya". Dalam ayat ini diceritakan bagaimana para pedagang yang menemukan Nabi Yūsuf as dalam perjalanan mereka akhirnya menjual Nabi Yüsuf as dengan harga yang sangat murah karena hati mereka tidak tertarik. Dalam hal ini kata kuncinya adalah "hati mereka tidak tertarik" (zuhud).
} 
tersebut. Inilah sikap zuhud. Zuhud bukan berarti menjauhi dunia tetapi menggenggam dunia tanpa kemelekatan hati terhadapnya.

Qanä'ah; kata ini sekilas diartikan sebagai sikap menerima. Karenanya kadang diselewengkan menjadi berarti sikap menerima apa adanya, semacam sikap menyerah pada keadaan. Padahal arti sebenarnya tidaklah demikian. Karena itu, Islam mengajarkan apa yang dinamai qanā'ah, namun itu bukan berarti menerima apa adanya, karena seseorang tidak dapat menyandang sifat qanā'ah kecuali setelah melalui lima tahap berikut: $^{20}$ a) Menginginkan kepemilikan sesuatu; b) Berusaha sehingga memiliki sesuatu itu, dan mampu menggunakan apa yang diinginkannya; c) Mengabaikan yang telah dimiliki dan diinginkan itu secara suka rela dan senang hati; d) Menyerahkannya kepada orang lain, dan merasa puas dengan apa yang dimiliki sebelumnya.

Tawakal; kata ini berasal dari kata wakkala yang mengandung arti pengandalan urusan kepada pihak lain ${ }^{21}$. Kata ini dengan segala perubahannya di dalam al-Qur'an terulang 70 kali. Bertawakal pada Allah berarti menyerahkan segala persoalan kepada-Nya. Konsep tawakal seperti ini dalam beberapa hal kadang disalahpahami sebagai sikap pengandalan yang menyebabkan manusia tidak perlu usaha sungguh-sungguh di dalam uruannya. Padahal di dalam al-Qur'an, kalau diperhatikan, keseluruhan ayat yang memerintahkan untuk bertawakal selalu didahului dengan perintah untuk menyempurnakan ikhtiar atau memaksimalkan usaha. Misalnya dalam QS. Al-Anfāl: 61, QS. Hūd: 123, QS. Al-Māidah: 23 dan QS. Ali Imrān: 159. Ketika ada seorang sahabat menemui Nabi saw., kemudian Nabi bertanya tentang untanya, dia menjawab: "Aku bertawakal pada Allah". Kemudian Nabi saw. meluruskan kekeliruannya tentang tawakal dengan bersabda: "Ikatklah untamu terlebih dahulu, setelah itu bertwakalah". Dari sini jelas tawakal bukan sikap mengandalkan kekuasaan Allah semata, tetapi tawakal adalah sikap yang dilakukan hanya ketika sudah memaksimalkan ikhtiar untuk mecapai sesuatu.

Syukur; selama ini syukur diungkapkan ketika seseorang memperoleh nikmat dari Allah SWT. Ini diungkapkan baik secara lisan maupun lainnya. Nampaknya sekarang ini, dan dalam rangka mengentaskan kemiskinan umat maka sebaiknya syukur yang biasanya hanya diungkapkan dari lisan dan hati, maka mari sekarang diungkapkan dengan melakukan pekerjaan secara lebih baik lagi. Ini sesuai dengan QS. Sabā': 13 yang artinya: "Bekerjalah

\footnotetext{
${ }^{20}$ M. Quraish Shihab, Wawasan Al-Qur'an: Tafsir Maudhu'i atas Pelbagai Persoalan Ummat,(Bandung: Penerbit Mizan, TT), 67

${ }^{21}$ Lihat Ibnu Faris, Mu'jam Maqāyis al-Lughah, 464
} 
wahai keluarga Daud untuk bersyukur (kapada Allah). Dan sedikit sekali dari hamba-hambaku yang bersyukur".

\section{b. Pada Ranah Keluarga dan Masyarakat Jaminan satu rumpun keluarga}

Boleh jadi karena satu dan lain hal seseorang tidak mampu memperoleh kecukupan untuk kebutuhan pokoknya, maka dalam hal ini alQuran datang dengan konsep kewajiban memberi nafkah kepada keluarga, atau dengan istilah lain jaminan antar satu rumpun keluarga sehingga setiap keluarga harus saling menjamin dan mencukupi.

"Orang-orang yang berhubungan kerabat itu sebagian lebih berhak terhadap sesamanya (daripada yang bukan kerabat)" (QS. Al-Anfāl [8]: 75).

"Dan berikanlah kepada keluarga dekat haknya, juga kepada orang miskin, dan orang yang berada dalam perjalanan... (QS. Al-Isrā' [17]: 26).

Ayat ini menggarisbawahi adanya hak bagi keluarga yang tidak mampu terhadap yang mampu. Dalam mazhab Abü Hanifah memberi nafkah kepada anak dan cucu, atau ayah dan datuk merupakan kewajiban walaupun mereka bukan muslim.

Para ahli hukum menetapkan bahwa yang dimaksud dengan nafkah mencakup sandang, pangan, papan dan perabotnya, pelayan (bagi yang memerlukannya), mengawinkan anak bila tiba saatnya, serta belanja untuk istri dan siapa saja yang menjadi tanggungannya.

"Hendaklah orang-orang yang mempunyai kelapangan, memberi nafkah sesuai dengan kelapangannya, dan barang siapa sempit rezekinya maka hendaklah ia memberi nafkah sesuai apa yang diberi Allah kepadanya (QS. Al-Ṭalāq, [65]: 7).

\section{Zakat}

Jelas bagi kita, bahwa keberhasilan orang kaya adalah atas keterlibatan banyak pihak, termasuk para fakir miskin: "Kalian mendapat kemenangan dan kecukupan berkat orang-orang lemah di antara kalian. Demikian Nabi saw. bersabda, sebagaimana diriwayatkan oleh Abū Daud melalui Abū al-Darda'. Kalau demikian, wajar jika Allah swt. mewajibkan kepada yang berkelebihan agar menyisihkan sebagian harta mereka untuk orang yang memerlukan. ${ }^{22}$

\footnotetext{
22 “Apabila kamu beriman dan bertakwa, Allah akan memberikan kepada kamu ganjaran, dan Dia tidak meminta harta bendamu (seluruhnya). Jika Tuhan meminta harta bendamu (sebagai zakat dan sumbangan wajib) dan Dia mendesakmu (agar engkau memberikan semuanya) niscaya kamu akan kikir, (karenanya Dia hanya meminta sebagian dan ketika itu bila kamu tetap kikir maka) Dia akan menampakkan kedengkian (kecemburuan sosial) antara kamu" (QS. Muhammad [47]: 36-37).
} 
Bukan di sini tempatnya menguraikan macam-macam zakat dan rinciannya, namun yang perlu digarisbawahi bahwa dalam pandangan hukum Islam, zakat harta yang diberikan kepada fakir miskin hendaknya dapat memenuhi kebutuhannya selama setahun, bahkan seumur hidup. Menutupi kebutuhan tersebut dapat berupa modal kerja sesuai dengan keahlian dan keterampilan masing-masing, yang ditopang oleh peningkatan kualitasnya. Hal lain yang perlu juga dicatat adalah bahwa pakar-pakar hukum Islam menetapkan kebutuhan pokok dimaksud mencakup kebutuhan sandang, pangan, papan, seks, pendidikan, dan kesehatan.

\section{c. Ranah Pemerintah}

Pemerintah juga berkewajiban mencukupi setiap kebutuhan warga negara, melalui sumber-sumber dana yang sah. Yang terpenting di antaranya adalah pajak, baik dalam bentuk pajak perorangan, tanah, atau perdagangan, maupun pajak tambahan lainnya yang ditetapkan pemerintah bila sumbersumber tersebut di atas belum mencukupi. Apa yang dilakukan pemerintah untuk mensejahterakan rakyatnya adalah kewajibannya, dan itu bukan merupakan kebaikannya.

\section{Pemberdayaan Kaum Du'afá' menurut Al-Qur'an}

\section{Pengertian dan Kriteria Du'afa' dalam al-Qur'an}

Du'afá' adalalah bentuk jamak dari kata da'îf. Kata ini berasal dari kata ḍa'afa (lemah), yang dengan berbagai derivasinya disebutkan 39 kali dalam al-Qur'an. Di antara ayat-ayat al-Qur'an yang mencantumkan kata da'afa yang berarti lemah, atau selain makna "berlipat ganda", bisa diklasifikasikan sebagai berikut:

- Lawan dari quwwah atau sinonim dari kata 'ajz. Ini di QS. al-Hājj (22): 73 dan QS. al-Nisā' (4): 76

- Lemah keyakinan atau antonim dari tegar. Ini dalam QS. Ali Imrān (3): 146 dan QS. al-Anfāl (8): 66

- Lemah fisik dan mental. Ini dalam QS. al-Rūm (30): 53 dan QS. alBaqarah (2): 282 dan QS. Hūd (11): 91

- Lemah jiwa, kemauan dan cita-cita. Ini dalam QS. al-Nisā' (4): 28

- Lemah ekonomi. Ini dalam QS. al-Nisā' (4): 9 dan QS. al-Baqarah (2): 266

- Lemah kedudukan atau lemah status. Ini dalam QS. Ibrāhim (14): 21 dan QS. Ghāfir (40): 47.

Dari klasifikasi di atas, jelas bahwa lemah ekonomi, yang biasanya dijadikan sebagai ikon dalam memahami makna ḍ ’afá, ternyata tidak 
dominan di dalam Al-Qur'an. Sebab, lemah ekonomi biasanya terlahir dari faktor-faktor eksternal, atau ia hanyalah sebuah akibat. ${ }^{23}$

Al-Qur'an telah menjelaskan tentang orang-orang yang tergolong d̦'afá', mereka antara lain; anak-anak yatim; orang-orang miskin; ibnu sabil (musäfir); orang yang meminta-minta; hamba sahaya (QS. al-Baqarah; 177); tuna netra; orang cacat fisik; orang sakit (QS. al-Nūr:61); manusia lanjut usia (QS. al-Isrā: 23); janda miskin (QS. al Baqarah: 240); orang yang berpenyakit sopak (lepra) (QS. Ali Imrān: 49); tahanan atau tawanan (QS. al-Insān: 78); mualaf (orang yang baru memeluk Islam, orang-orang fakir; orang-orang yang berutang (ghärimin); orang yang berjuang di jalan Allah (fî sabilillah) (QS. al-Taubah: 60); buruh atau pekerja kasar (QS. al-Ṭalāq: 6); nelayan (QS. al-Kahfi:79); rakyat kecil yang tertindas (QS. al-Nisā' :75); anak-anak kecil dan bayi (QS. al- An'ām:140) ${ }^{24}$

\section{Perintah Berbuat Baik dan Memenuhi Hak Hak Kaum Dhu'afâ}

Allah swt. dalam al-Qur'an telah memerintahkan kepada hamba-Nya agar berbuat baik kepada kaum dúafă. Salah satu ayatnya menyatakan," dan berbuat kebaikanlah kepada ibu bapa, kaum kerabat, anak-anak yatim, dan orang-orang miskin," (QS. Al-Baqarah: 83). Perintah berbuat baik kepada mereka ini, antara lain, mengucapkan perkataan yang baik kepada mereka (QS. al-Nisā': memuliakan mereka (QS. al-Nisā': 36) memelihara, mengasuh, dan mengurus mereka secara patut (QS. al-Nisā': 127); menggauli mereka sebagai saudaranya sendiri (QS. al-Baqarah: 177); memberikan mereka nafkah (QS. al-Baqarah: 215); memberikan mereka harta (QS. al-Baqarah: 177); memberikan mereka makan (al-Insān:8); memberi mereka sedekah (QS. al-Baqarah: 272); memperbaiki tempat tinggal mereka dan melindungi harta mereka (QS. al-Kahfi: 82); membela (QS. al-Nisā': 75); melindungi mereka dari kezaliman (QS. al-Kahfi: 79); mengobati mereka yang sakit (QS. Ali Imrān: 49); mengajak mereka makan bersama (QS. al-Shu'arā': 61); memberikan mereka pendidikan dan pengajaran yang baik (QS. 'Abasa: 1-11); memelihara mereka dengan penuh kasih sayang dan sopan santun (al-Isrā': 23); memaafkan dan berlapang dada pada mereka (QS. al-Nūr: 22); mengucapkan perkataan yang sopan (QS. alIsrā': 23); serta memberi nasihat dan mendakwahkan mereka (QS. Yūsuf: $30-41)$

\footnotetext{
${ }^{23}$ Tim Penyusun, "Pemberdayaan Kaum Dhu'afa" dalam Tafsir Tematik: Al-Qur'an dan Pemberdayaan Kaum Dhu'afa, (Jakarta: Lajnah Pentashuhan Al-Qur'an Badan Litbang Kementerian Agama RI, 2008), 14-15..

${ }^{24}$ gemabaiturrahman.com, mitraummat.org
} 
Allah swt. dalam al-Qur'an juga telah memerintahkan kepada umatNya agar memenuhi hak-hak kaum du'afá. Diantaranya Allah swt. menyatakan, "dan berikanlah kepada keluarga-keluarga yang dekat akan haknya, kepada orang miskin dan orang yang dalam perjalanan dan janganlah kamu menghambur-hamburkan (hartamu) secara boros." (QS. alIsrā': 26.).

Adapun hak-hak kaum dhu'afâ adalah memperoleh zakat (QS. alTaubah: 60); infaq (QS. al-Baqarah: 273); fidyah (denda bagi orang yang berat dalam berpuasa) (QS. al-Baqarah: 184); harta warisan orang tua (QS. al-Nisā': 5) ghanīmah (harta rampasan perang (QS. al-Anfāl: 41) fai (harta rampasan daerah musuh) (QS. al-Hashr: 7); denda zhihār (sanksi memandang isteri sebagai ibu kandung) (QS. al-Mujādillah: 2-4); kafärat sumpah (sanksi karena bersumpah palsu) (QS. al-An'ām: 89); harta warisan orang lain (QS. al-Nisā': 8); zakat hasil panen kebun atau pertanian (QS. alAn'äm: 141); zakat hasil pengembakbiakan dan penjualan hewan (QS. alAn'ām: 142); zakat emas dan perak (QS. al-Taubah: 34-35); upah pekerja (QS. al-Wāqi'ah: 6); pendidikan dan pengajaran yang sama (QS. 'Abasa: 13); perlindungan hukum(QS. al-Kahfi: 79 \& 82); memberi daging kurban (QS. al-Hājj: 34-35) dan jaminan sosial (QS. al-Taubah: 60 dan 103).

\section{Solusi Pemberdayaan Kaum Dhu'afâ}

Untuk menyelesaikan persoalan kaum dhuafa dalam ekonomi serta sosial kemasyarakatan, Islam menawarkan solusinya melalui zakat, sedekah, infak dan bentuk lainnya yang di halalkan oleh islam. Zakat merupakan komponen dominan dalam pemberdayaan mereka. Karena zakat dapat berfungsi sebagai berikut:

Pertama, sebagai perwujudan iman kepada Allah swt. mensyukuri nikmat-Nya, menumbuhkan akhlak mulia dengan memiliki rasa kepedulian yang tinggi, menghilangkan sifat kikir dan rakus, menumbuhkan ketenangan hidup, sekaligus mengembangkan dan mensucikan harta yang dimiliki.

Kedua, menolong, membantu dan membina mereka kaum dhuafa, ke arah kehidupan yang lebih baik dan lebih sejahtera, sehingga mereka dapat memenuhi kebutuhan hidupnya dengan layak, dapat beribadah kepada Allah swt. terhindar dari bahaya kekufuran, sekaligus menghilangkan sifat iri, dengki dan hasud yang mungkin timbul dari kalangan mereka ketika melihat golongan kaya yang berkecukupan hidupnya.

Zakat, sesungguhnya bukan sekadar memenuhi kebutuhan konsumtif yang sifatnya sesaat, akan tetapi memberikan kecukupan dan kesejahteraan pada mereka, dengan cara menghilangkan atau memperkecil penyebab kehidupan mereka menjadi miskin dan menderita. 
Ketiga, sebagai pilar jamā'̄ (sosial) antara kelompok aghniyā' yang berkecukupan hidupnya, dengan para mujahid yang waktunya sepenuhnya untuk berjuang di jalan Allah swt., sehingga tidak memiliki waktu yang cukup untuk berusaha bagi kepentingan nafkah diri dan keluarganya (QS. alBaqarah, ayat 273 ).

Keempat, salah satu sumber dana bagi pembangunan sarana maupun prasarana yang harus dimiliki ummat Islam, seperti sarana pendidikan, kesehatan, maupun sosial ekonomi dan terlebih lagi bagi peningkatan kualitas sumber daya manusia.

Kelima, untuk memasyarakatkan etika bisnis yang benar, karena zakat tidak akan diterima dari harta yang didapatkan dengan cara batil.

Keenam, dari sisi pembangunan kesejahteraan umat, zakat merupakan salah satu instrumen pemerataan pendapatan. Zakat yang dikelola dengan baik, sangat dimungkinkan dapat membangun pertumbuhan dan pemrataan. $^{25}$

\section{Penyelesaian Konflik Sosial Menurut al-Qur'an Konflik Sosial dalam Perspektif Al-Qur' an}

Islam (baca: al-Qur'an) tidak pernah memungkiri adanya konflik dalam masyarakat. Manusia sebagai makhluk Allah mempunyai sifat yang unik dan berlainan antara satu dengan lainnya. Sehingga perbedaan pendapat dalam berpikir, menilai dan mengambil keputusan merupakan tabiat yang alamiah. Mau tidak mau, akan sukar sekali untuk mewujudkan satu kehidupan dan hubungan kemanusian yang berlandaskan satu pendapat dan satu keinginan saja. Kehidupan tanpa perselisihan boleh dikatakan tidak mungkin kalau organisasi itu ingin memiliki prestasi dan produktifitas yang tinggi. "Jikalau Tuhanmu menghendaki, tentu Dia menjadikan manusia umat yang satu, tetapi mereka senantiasa berselisih pendapat”. (QS. Hūd:118).

Dalam Islam (baca: al-Qur'an), konflik tidak harus dipahami sebagai gejala yang destruktif, dan kontra-produktif, namun bisa menjadi gejala yang konstruktif bahkan produktif. Keberadaan konflik sebagai unsur pembawaan sangat penting dalam kehidupan manusia. Kehidupan tidak dapat berjalan dengan baik tanpa ada konflik. Selagi konflik masih dibutuhkan manusia, maka mereka pun dibekali oleh Allah dengan

\footnotetext{
${ }^{25}$ Untuk bacaan lebih lanjut, silahkan baca di Tim Penyusun, "Pemberdayaan Kaum Dhu'afa" dalam Tafsir Tematik: Al-Qur'an dan Pemberdayaan Kaum Dhu'afa, (Jakarta: Lajnah Pentashihan al-Qur' an Badan Litbang Kementerian Agama RI, 2008)
} 
kemampuan untuk berkonflik, baik dalam fisik, roh maupun akalnya, dan sekaligus kemampuan untuk mencari solusinya. ${ }^{26}$

Islam memandang konflik bukan sebagai tujuan namun lebih sebagai sarana untuk memadukan antara berbagai hal yang saling bertentangan untuk membebaskan kehidupan manusia dari kepentingan individual, sehingga tidak membiarkan perbedaan-perbedaan itu menjadi penyebab adanya permusuhan. Islam selalu mengingatkan bahwa sesungguhnya manusia berasal dari asal yang sama.

"Hai sekalian manusia, bertakwalah kepada Tuhan-mu yang telah menciptakan kamu dari diri yang satu, dan dari padanya Allah menciptakan istrinya; dan dari pada keduanya Allah memperkembangbiakkan laki-laki dan perempuan yang banyak. dan bertakwalah kepada Allah yang dengan (mempergunakan) nama-Nya kamu saling meminta satu sama lain, dan (peliharalah) hubungan silaturrahim. Sesungguhnya Allah selalu menjaga dan mengawasi kamu”. (QS. al-Nisā': 1)

\section{Etika al-Qur'an dalam Manajemen Konflik}

Di dalam agama Islam juga dijelaskan tentang tata cara mengelola suatu konflik agar konflik tidak bersifat destruktif melainkan menjadi hal yang bermanfaat. Islam memandang konflik terjadi karena tingkah laku atau sikap manusia dalam sebuah organisasi yang tidak mempraktikkan nilai-nilai atau etika yang baik, seperti amanah, adil, bertanggung jawab dan sebagainya. Pengabaian terhadap etika yang baik menyebabkan manusia melakukan tindakan tidak terpuji (madhmümah), seperti gila jabatan, menindas (eksploitatif), iri dan dengki, tidak jujur dan sebagainya. ${ }^{27}$

Oleh karena itu, langkah pertama dalam mengelola suatu konflik adalah meningkatkan program-program yang sasarannya adalah memperkuat keimanan anggota organisasi. Aktivitas ini dapat meliputi program seminar, ceramah, ataupun bengkel kerohanian yang dapat meningkatkan perasaan atau sikap bertanggungjawab dan mengurangi perasaan atau sikap mementingkan diri sendiri. Agama Islam menegaskan bahwa manusia perlu meningkatkan keimanannya agar Allah swt. berkenan menyatukan hati manusia yang cenderung tidak bersatu dengan yang lainnya. "Dan Yang mempersatukan hati mereka (orang-orang yang beriman). Walaupun kamu membelanjakan semua (kekayaan) yang berada di bumi, niscaya kamu tidak

\footnotetext{
${ }^{26}$ Ariejo Isnoer Narjono, Manajemen Konflik Organisasi dalam Pandangan Islam, Jurnal JIBEKA, Vol. 8 No.1 Februari 2014, STIE ASIA Malang.

27 Al-Qudsi, Syarifah Hayati Syed Ismail \& Abu Bakar, Mohd Mauli Azli Bin, Etika Penyelesaian Konflik dalam Pentadbiran Islam: Suatu perbandingan. Malaysia, University of Malaya, Jurnal Syariah, 14:1, 1-22
} 
dapat mempersatukan hati mereka, akan tetapi Allah telah mempersatukan mereka”. (QS. Al-Anfäl: 63).

Budaya kerja tim (berkelompok) sangat dianjurkan oleh agama Islam guna mencegah atau mengurangi konflik ${ }^{28}$. Pembentukan satuan tugas (satgas) atau panitia tertentu untuk melaksanakan suatu proyek dapat mendorong anggota organisasi untuk bekerjasama dalam mencapai tujuan yang satu. Dengan budaya kerja tim ini, secara tidak langsung dapat mempererat hubungan silaturahim dan menciptakan sikap saling memahami antara mereka. Konsep persaudaraan atau persahabatan ini amat ditekankan dalam Islam. "Sesungguhnya orang-orang mukmin bersaudara karena itu damaikanlah antara kedua saudaramu”. (QS. Al-Hujurāt:10).

Konflik juga bisa diarahkan sebagai gejala yang konstruktif dan produktif dengan cara mengembangkan sikap saling menghormati dan kemauan untuk saling mengenal dengan yang lainnya. Perbedaan warna kulit, bangsa, bahasa dan sebagainya memang sering menjadikan manusia berlainan dari segi pemikiran, pandangan, persepsi, kepribadian dan pemahaman. Tetapi perbedaan ini hendaknya dipahami sebagai perintah Allah swt. untuk saling mengenal dan bekerjasama antara satu dan lainnya dan bukan untuk permusuhan. "Hai manusia, sesungguhnya Kami menciptakan kamu dari seorang laki-laki dan seorang perempuan dan menjadikan kamu berbangsa-bangsa dan bersuku-suku supaya kamu saling kenal mengenal. Sesungguhnya orang yang paling mulia di antaramu di sisi Allah ialah orang yang paling bertakwa”. (QS. Al-Hujurāt:13).

Konsep musyawarah telah dianggap sebagai salah satu mekanisme dalam sistem manajemen yang Islami. Hal ini dapat dibuktikan dengan keberhasilan pemerintahan Rasulullah saw.. dan Khulafá', al-Rāshidin dalam membangun dan mengembangkan kota Madinah yang penduduknya mempunyai latarbelakang yang berbeda. ${ }^{29}$ Salah satu prinsip pemerintahan Qur'ani bagi masyarakat plural yang dicontohkan Beliau dan para sahabatnya adalah musyawarah sebagai mekanisme penyelesaian konflik. "Dan (bagi) orang yang mau menerima (mematuhi) seruan Tuhannya dan mendirikan salat, sedang urusan mereka (diputuskan) dengan musyawarat antara mereka”. (QS. Al-Shūrā: 38).

\footnotetext{
28 Al-Qudsi, Syarifah Hayati Syed Ismail \& Abu Bakar, Mohd Mauli Azli Bin, Etika Penyelesaian Konflik dalam Pentadbiran Islam: Suatu perbandingan. Malaysia, University of Malaya, Jurnal Syariah, 14:1, 1-22

29 Al-Qudsi, Syarifah Hayati Syed Ismail \& Abu Bakar, Mohd Mauli Azli Bin, Etika Penyelesaian Konflik dalam Pentadbiran Islam: Suatu perbandingan. Malaysia, University of Malaya, Jurnal Syariah, 14:1, 1-22
} 
Selain musyawarah, metode konfrontasi (perdebatan) dapat merupakan salah satu cara dalam mengelola konflik dalam organisasi. Dalam al-Qur'an, perdebatan sering merujuk pada upaya kompetisi yang dilakukan kaum muslim dengan kaum non muslim. Debat sering digunakan oleh Nabi Allah untuk menanggapi segala tuduhan terhadap agama Islam sekaligus meyakinkan pihak lain tentang kebenaran agama Islam. Perdebatan lebih menunjukkan sebagai upaya untuk meyakinkan pihak lain, dan tidak mungkin terjadi kompromi, dan yang mungkin hanya sebatas memahami saja, bukan untuk saling membenarkan satu sama lain. Di dalam al-Qur'an juga di jelaskan bahwa berdebat harus dilakukan dengan adil dan fair. "Serulah (manusia) kepada jalan Tuhan-mu dengan hikmah dan pelajaran yang baik dan berdebatlah dengan mereka dengan cara yang baik. Sesungguhnya Tuhanmu Dialah yang lebih mengetahui tentang siapa yang tersesat dari jalan-Nya dan Dialah yang lebih mengetahui orang-orang yang mendapat petunjuk. (QS. Al-Nahl: 125)

Dari beberapa penjelasan diatas dapat dipahami bahwa Islam banyak menggunakan cara-cara damai sebagai cara untuk mengelola konflik. Islam menganjurkan kepada pemeluknya untuk memiliki sikap toleransi terhadap perbedaan yang dimiliki tiap-tiap manusia. Karena perbedaan itu merupakan kodrat Allah swt. yang tidak bisa ditolak. Perbedaan itu diciptakan untuk saling melengkapi, dan dengan perbedaan itu manusia akan terus berkembang dan menciptakan perubahan-perubahan yang nantinya akan bermanfaat bagi manusia pada umumnya.

Meskipun begitu, Islam (baca Al-Qur'an). masih memberi kesempatan untuk mengambil tindakan tegas manakala cara-cara damai tidak dapat mengarahkan konflik untuk berperan fungsional atau membantu kegiatan organisasi. Manajer boleh melakukan penekanan, mengambil tindakan disiplin atau sangsi sampai pemecatan dengan tujuan menjaga kelangsungan hidup organisasi. ${ }^{30}$ Penggunaan metode seperti ini dibolehkan dalam Islam dengan tetap mengutamakan perdamaian dan berpegang teguh pada prinsip keadilan. "Dan jika ada dua golongan dari orang-orang mukmin berperang maka damaikanlah antara keduanya. Jika salah satu dari kedua golongan itu berbuat aniaya terhadap golongan yang lain maka perangilah golongan yang berbuat aniaya itu sehingga golongan itu kembali, kepada perintah Allah; jika golongan itu telah kembali (kepada perintah Allah), maka damaikanlah

30 Sarif, Suhaili; Noordin, Kamaruzaman \& Abdullah, Ahmad Sufian Che, Managing Organizational Conflict from Islamic perspective. Malaysia, University of Malaya, Jurnal Syariah,12:2,p.107s/d122,2004.OnLine:http://myais.fsktm.um.edu.my/6980/1/Managing_Org anization Conflict From Islamic Perspective.pdf. Diakses Tanggal 25 september 2013 
antara keduanya dengan adil dan berlaku adillah. Sesungguhnya Allah menyukai orang-orang yang berlaku Adil”. (QS. Al-Hujurāt: 9).

\section{Epilog}

\section{Solusi Al-Qur'an untuk Problem Kemiskinan Umat}

Pada ranah individual, untuk mengatasi problem kemiskinan umat Islam, al-Qur'an mendorong individu-individu muslim untuk selalu bekerja keras, guna meningkatkan ekonomi dan kehidupannya. Sebagaimana terdapat dalam QS. al-Inshirāh [94]: 7-8. Tafsir ayat ini dikuatkan oleh pernyataan-pernyataan hadis yang sejalan. Motivasi untuk maju secara ekonomi, begitu ditekankan dalam al-Qur'an, bahkan pun jika harus pindah atau hijrah ke daerah atau kondisi yang memungkinkan untuk maju. Ini sebagaimana dalam QS. al-Nisā' [4]: 100.

Untuk meningkatkan etos kerja pada ranah individual, perlu reinterprestasi dan pemaknaan ulang terhadap terma-terma agama yang diambil dari al-Qur'an (Islam) yang selama ini diasumsikan sebagai pelestari kejumudan umat dalam bidang ekonomi. Terma-terma tersebut adalah zuhud, qana'ah, tawakal dan syukur. Selama ini, terma-terma tersebut dipahami secara negatif, sehingga dimungkinkan dapat menghambat individu muslim dalam meraih kemajuan ekonomi, dan dalam beberapa hal dianggap dapat melanggengkan kemiskinan. Pemaknaan ulang tersebut menjadi penting, agar zuhud, qana'ah, tawakal dan syukur bisa dimaknai secara positif.

Pada ranah keluarga, menghadapi problem kemiskinan, al-Qur'an mewajibkan kepada setiap orang untuk menyantuni atau menafkahi orangorang yang memang wajib dinafkahi dalam suatu (rumpun) keluarga. Ini ada dalam QS. Al-Anfāl [8]: 75 dan QS. Al-Isrā' [17]: 26, dan QS. Al-Anfāl [8]: 75. Kewajiban menyantuni kerabat keluarga ini bagi yang memiliki kelapangan. Adapun yang disantuni adalah mereka yang kurang mampu. Mereka yang kurang mampu ini memiliki hak dari harta mereka yang mampu dan berkecukupan. Ini sebagaimana di QS. Al-Dhāriyāt [51]: 19.

Dengan menyeru atau bahkan mewajibkan pada yang mampu untuk menyantuni keluarganya yang tidak atau kurang mampu, maka problem kemiskinan dalam ranah keluarga dan masyarakat diharapkan bisa teratasi.

Selain itu, dalam ranah masyarakat, untuk mengatasi problem kemiskinan, al-Qur'an mensyariatkan wajibnya muslim membayar zakat. Kewajiban zakat dari para muzakki kepada para mustahiq di masyarakat ini, selain sebagai bentuk melaksanakan ibadah yang diperintahkan Allah swt. kepada umat Islam, juga sebagai upaya untuk menumbuhkan keharmoniasan sosial, mengurangi kesenjangan sosial antara yang mampu dan yang kurang 
mampu. Zakat bisa ikut mengurangi dampak kemiskinan. Selain itu, bila dikelola dengan baik, zakat bisa bernilai produktif, sehingga turut aktif meningkatkan perekonomian masyarakat secara riil.

Sedangkan pada ranah pemerintah, pemerintah berkewajiban mencukupi setiap kebutuhan warga negara, melalui sumber-sumber dana yang sah.

\section{Solusi Al-Qur'an untuk Problem Kaum Du'afa'}

Du'afá' dalam ayat-ayat al-Qur'an bukan hanya menunjuk pada mereka yang lemah secara ekonomi, tetapi juga berarti lemah secara fisik, mental, lemah kemauan, lemah cita-cita dan lemah status (kedudukan). Lemah ekonomi, yang biasanya dijadikan sebagai ikon dalam memahami makna dúafá, ternyata tidak dominan di dalam Al-Qur'an. Sebab, lemah ekonomi biasanya terlahir dari faktor-faktor eksternal, atau ia hanyalah sebuah akibat. ${ }^{31}$

Dalam ayat-ayatal-Qur'an menyebut mengenai hak-hak kaum du'afä, kewajiban kita untuk memperhatikan mereka, imbalan dari Allah jika kita memperhatikan mereka, akibat-akibat jika kita menelantarkan mereka, dan juga mengenai cara-cara untuk membantu dan memberdayakan mereka.

Untuk menyelesaikan persoalan kaum du'afă' dalam ekonomi serta sosial kemasyarakatan, Islam menawarkan solusinya melalui zakat, sedekah, infak dan bentuk lainnya yang di halalkan oleh Islam. Zakat merupakan komponen dominan dalam pemberdayaan mereka. Karena zakat dapat berfungsi sebagai berikut: Pertama, sebagai perwujudan iman kepada Allah swt. mensyukuri nikmat-Nya, menumbuhkan akhlak mulia dengan memiliki rasa kepedulian yang tinggi, menghilangkan sifat kikir dan rakus, menumbuhkan ketenangan hidup, sekaligus mengembangkan dan mensucikan harta yang dimiliki.

Kedua, menolong, membantu dan membina mereka kaum du'afá', ke arah kehidupan yang lebih baik dan lebih sejahtera, sehingga mereka dapat memenuhi kebutuhan hidupnya dengan layak, dapat beribadah kepada Allah SWT, terhindar dari bahaya kekufuran, sekaligus menghilangkan sifat iri, dengki dan hasud.

Ketiga, sebagai pilar jamā', antara kelompok aghniyā' yang berkecukupan hidupnya, dengan para mujahid yang waktunya sepenuhnya untuk berjuang di jalan Allah swt., sehingga tidak memiliki waktu yang

\footnotetext{
${ }^{31}$ Tim Penyusun, "Pemberdayaan Kaum Dhu'afa" dalam Tafsir Tematik: Al-Qur'an dan Pemberdayaan Kaum Dhu'afa, (Jakarta: Lajnah Pentashuhan Al-Qur'an Badan Litbang Kementerian Agama RI, 2008), 14-15.
} 
cukup untuk berusaha bagi kepentingan nafkah diri dan keluarganya (QS. Al-Baqarah, ayat 273 ).

Keempat, salah satu sumber dana bagi pembangunan sarana maupun prasarana yang harus dimiliki umat Islam, seperti sarana pendidikan, kesehatan, maupun sosial ekonomi dan terlebih lagi bagi peningkatan kualitas sumber daya manusia.

Kelima, untuk memasyarakatkan etika bisnis yang benar, karena zakat tidak akan diterima dari harta yang didapatkan dengan cara bathil.

Keenam, dari sisi pembangunan kesejahteraan ummat, zakat merupakan salah satu instrumen pemerataan pendapatan. Zakat yang dikelola dengan baik, sangat dimungkinkan dapat membangun pertumbuhan ekonomi dan pemerataan pendapatan, yang pada giliranya akan berdampak kepada kaum ḍu'afă'.

\section{Solusi Al-Qur'an untuk Konflik Sosial}

Dalam menghadapi konflik sosial, al-Qur'an mengajarkan bahwa dalam menangani konflik, diperlukan etika. Etika untuk memenej konflik ini, diajarkan dalam beberapa ayat al-Qur'an. Langkah pertama dalam mengelola konflik adalah meningkatkan program-program yang sasarannya adalah memperkuat keimanan. Aktivitas ini dapat meliputi program seminar, ceramah, ataupun bengkel kerohanian yang dapat meningkatkan sikap yang bertanggungjawab dan mengurangi sikap mementingkan diri sendiri. Agama Islam menegaskan bahwa manusia perlu meningkatkan keimanannya agar Allah swt. berkenan menyatukan hati manusia yang cenderung tidak bersatu dengan yang lainnya. Ini sesuai dengan QS. AlAnfāl: 63 .

Al-Qur'an juga mengajurkan adanya budaya kerja tim (berkelompok) guna mencegah atau mengurangi konflik dan memupuk persaudaraan atau persahabatan. Ini sesuai dengan QS. al-Hujurāt:10.

Konflik juga bisa diarahkan sebagai gejala yang konstruktif dan produktif dengan cara mengembangkan sikap saling menghormati dan kemauan untuk saling mengenal dengan yang lainnya. Ini sesuai dengan (QS. al- Hujurāt:13).

Bila konflik terjadi, al-Qur'an menawarkan musyawarah sebagai mekanisme penyelesaian konflik. Ini sesuai dengan QS. Al-Shūrā: 38. Selain itu, perdebatan yang baik juga bisa digunakan. Ini sesuai dengan QS. alNahl: 125.

Demikian itu adalah cara-cara damai dalam menengani konflik. AlQur'an masih memberi kesempatan untuk mengambil tindakan tegas 
manakala cara-cara damai tidak menyelesaikan konflik. Ini sesuai dengan QS. Al-Hujurāt: 9.

\section{Daftar Pustaka}

Ashgar Ali Enginer, Islam and Liberation Theology: Essay and Liberative Elements in Islam, terj. Islam dan Teologi Pembebasan, Yogyakarta: LKiS, 2004

Abdul Djalal, Urgensi Tafsir Maudlu'i Pada Masa Kini, Jakarta: Kalam Mulia, 1990

Abd al-Hayy al-Farmāwī, al-Bidāyah fí al-Tafsìr al Maựūî, Kairo: Mathba'ah al-Hadarah al-Arabiyah, 1977

Abd al-Hayy al-Farmāwī, Mu'jam al-Alfāz wa al-A'lām al-Qur'āniyah, Kairo: Dār al-'Ulūm, 1968

Ahmad Baidowi, "Terorisme dan Perdamaian dalam Islam" dalam buku Alim Ruswanto dan Abdul Mustaqim (ed.), Antologi Isu-isu Global dalam Kajian Agama dan Filsafat, Yogyakarta: PPS UIN Sunan Kalijaga dan Idea Press, 2010

Al-Qurthubi, Al-Jāmi' al-Ahkkām Beirūt: Dār Fikr, 1999, jilid 8

Alim Ruswanto, "Islam untuk Resolusi Konflik dan Pembangunan Perdamaian”. Alim Ruswanto dan Abdul Mustaqim (ed.), Antologi Isu-isu Global dalam Kajian Agama dan Filsafat,Yogyakarta: PPS UIN Sunan Kalijaga dan Idea Press, 2010

Ali Mursyid, Al-Qur'an dan Kemiskinan Umat, Jurnal al-Fanar, Tafsir Hadits Fakultas Ushuluddin IIQ Jakarta, Vol. 1, No. 2, Desember 2009

Al-Qudsi, Syarifah Hayati Syed Ismail \& Abu Bakar, Mohd Mauli Azli Bin, Etika Penyelesaian Konflik dalam Pentadbiran Islam: Suatu perbandingan. Malaysia, University of Malaya, Jurnal Syariah, TT

Ariejo Isnoer Narjono, Manajemen Konflik Organisasi dalam Pandangan Islam, Jurnal JIBEKA, Vol. 8 No.1 Februari 2014, STIE ASIA Malang.

Benni Setiawan, Agama dan Kemiskinan, Republika edisi 02 Februari 2008

Didin Hafidhuddin, Zakat Sebagai Tiang Utama ekonomi Syariah, Makalah disampaikan pada acara Seminar Bulanan Masyarakat ekonomi Syariah, Jakarta, Aula bank Mandiri Tower, 2006

Faizah Ali Syibromalisi, Dhu'afâ dan Mustadh'afin di dalam Islam, dalam http://www.pesantreniiq.or.id/index.php/artikel/294-dhuafa-danmustadhafin-dalam-islam

Hardiansya Suteja, Kepedulian Sosial Menurut Al-Qur'an. sumber: www. wordpress.com, edisi 21 Desember 2007 
Luis Ma'luf, al-Munjid fī al-Lughah wa al-A 'lām, Beirut: Dār al-Mashriq, , 1987

Moch. Nurhakim, Islam Tradisi Reformasi: PragmatismeAgama dalam Pemikiran Hasan Hanafi, TK: Bayumedia Publishing, 2003

Muhammad Shahrur, al-Kitāb wa Al-Qur'ān, Qirā'ah Mu'āsirah, Damaskus: TP, TT

Muhammad Quraish Shihab, "Fungsi dan Peran Wahyu dalam Kehidupan Masyarakat" dalam Membumikan al-Qur'an, Bandung: Mizan, 2003

Muhammad Quraish Shihab, Wawasan al-Qur'an: Tafsir Maudhu'i atas Pelbagai Persoalan Ummat, Bandung: Penerbit Mizan, TT

Muhammad Husain Haekal, Sejarah Hidup Muhammad, terjemah Ali Audah ,Jakarta: Balai Pustaka, 1980

Richard Osborne \& Borin Van Loon, Mengenal Sosiologi For Beginner. Bandung: Mizan, 1996

Suroyo, dkk, Agama dan Kepercayaan membawa Pembaruan., Jogjakarta: Kanisius, 2006

Siahaan, N.H.T., Hukum Lingkungan dan Ekologi Pembangunan, Jakarta: Erlangga, 2004

Sarif, Suhaili; Noordin, Kamaruzaman \& Abdullah, Ahmad Sufian Che, Managing Organizational Conflict from Islamic perspective. Malaysia, University of Malaya, Jurnal Syariah,12:2, p.107s/d 122,2004.OnLine:http://myais.fsktm.um.edu.my/6980/1/Managing_ Organization Conflict From Islamic Perspective.pdf. Diakses Tanggal 25 september 2013

Sya'labi, al-Nubuwwah wa al-Anbiyā', (Beirūt: Dār al-Fikr, TT

Soerjono Soekanto, Sosiologi Suatu Pengantar, Jakarta: Rajawali Press, 1982

Samuel P. Huntington, Benturan Antarperadaban dan Masa Depan Politik Dunia, terjemah M. Sadat Ismail, Yogyakarta: Qalam, 2001

Tim Penyusun, "Pemberdayaan Kaum Miskin" dalam al-Qur'an dan Pemberdayaan Kaum Du'afá, Jakarta: Lajnah Pentashihan alQur'an Badan Litbang dan Diklat Departemen Agama RI, 2008

Tim Penyusun, "Konflik Sosial”, dalam al-Qur'an dan Isu-isu Kontemporer I, Jakarta: Lajnah Pentashihan al-Qur'an Badan Litbang dan Diklat Kementerian Agama RI, 2012

Tim Penyusun, “Transplantasi Organ Tubuh”, dalam al-Qur'an dan Isu-isu Kontemporer II, Jakarta: Lajnah Pentashihan al-Qur'an Badan Litbang dan Diklat Kementerian Agama RI, 2012

Tim Penyusun Departemen Pendidikan dan Kebudayaan, Kamus Besar Bahasa Indonesia, Jakarta: Balai Pustaka, TT 